\title{
KOMPETENSI KEPRIBADIAN PENDIDIK PERSPEKTIF PENDIDIKAN ISLAM
}

\author{
Imam Fahrudin \\ Universitas Muhammadiyah Malang, Indonesia \\ E-mail: fahrudinimam911@gmail.com
}

\begin{abstract}
Abstrak
Pendidik merupakan aktor utama yang bertanggung jawab dalam mengembangkan seluruh potensi peserta didik pada proses pendidikan. Output yang dihasilkan proses pendidikan tentunya tergantung pendidik sebagai role model bagi peserta didiknya. Tugas untuk mengelola proses pembelajaran adalah hal yang tidak mudah bagi seorang pendidik. Tuntutan untuk profesional dibuktikan dengan serangkaian kompetensi yang harus dikuasai. Salah satu kompetensi yang harus dimiliki pendidik adalah kompetensi kepribadian. Pendidik atau guru adalah figur yang ditiru dalam pengetahuannya maupun kepribadiannya. Masalah dewasa ini adalah tidak sedikit pendidik yang kurang profesional dalam memposisikan dirinya di hadapan peserta didik. Studi ini akan mencari acuan bagi kompetensi kepribadian guru dalam perspektif Islam. Pembahasan ditulis melalui penggalian data dengan kajian kepustakaan. Hasilnya diketemukan tujuh belas kepribadian yang harus dimiliki oleh seorang guru. Tujuh belas kepribadian yang dirumuskan dalam studi ini akan membentuk guru dengan kepribadian seorang muslim. Selain itu juga menanamkan karakter Islami dan lebih dekat dengan peserta didik, sehingga guru akan lebih berhasil mengelola proses pembelajaran.
\end{abstract}

\section{Kata Kunci: Pendidikan Islam, Guru, Kompetensi Kepribadian}

\begin{abstract}
The teacher is the main actor responsible for developing the full potential of students in the education process. The output produced by the educational process certainly depends on the educator as a role model for students. The task of managing the learning process is not easy for an educator. The demands for a teacher's professionalism are proven by a series of competencies that must be mastered. One of the competencies that must be possessed by educators is personality competence. Educator or teacher are figures who are emulated in their knowledge and personality. The problem today is that not a few teachers are less professional in positioning themselves in front of students This study will look for references for teacher personality competencies in an Islamic perspective. The discussion was written through data mining with literature study. The result found seventeen personalities that must be owned by a teacher. Seventeen personality points formulated in this study will form a teacher with a Muslim personality. It also instills Islamic character and is closer to students, so that the teacher will be more successful in managing the learning process.
\end{abstract}


Keywords: Islamic Education, Personality Competence, Teacher

\section{Pendahuluan}

Pendidik secara umum dapat diartikan sebagai sumber daya manusia yang bertanggung jawab dan bersentuhan langsung dalam mengembangkan potensi peserta didik secara komprehensif. Pendidik sejatinya adalah role model bagi peserta didik. Pendidik hari ini bukan hanya dituntut menggugurkan kewajiban dengan mentransfer pengetahuan saja namun juga sebagai suri tauladan peserta didik. Ini sejalan dengan kondisi dewasa ini di mana orang tua mempercayakan sepenuhnya anaknya kepada lembaga pendidikan, maka peran pendidik bukan saja mengajar tapi juga mendidik peserta didiknya. ${ }^{1}$ Guru dalam pendidikan Islam digadang-gadang memiliki sifat-sifat terpuji, yakni kepiawaian, berilmu, dan merupakan pribadi yang mampu mengelola pembelajaran yang berkesan sehingga dapat diminati dan dihayati peserta didik. ${ }^{2}$

Kepribadian sangat mempengaruhi perannya sebagai pendidik yang mengajar dan mendidik. Pengelolaan pengajaran berhasil bukan saja dengan strategi pembelajaran yang digunakan namun juga kepribadian pendidik secara keseluruhan. Dengan kata lain, proses pendidikan yang diperankan oleh pendidik terhadap peserta didik dilakukan dengan interaksi formal dan informal. Maka dari itu, kepribadian pendidik bisa disebut perantara dalam menyukseskan proses mengajar dan mendidik. ${ }^{3}$ Dewasa ini, kita membutuhkan pendidik yang bukan hanya melaksanakan tuntutan pekerjaan dan materil tetapi juga yang berangkat berdasarkan panggilan hati, tulus untuk mengabdi.

Pendidik atau juga disebut guru adalah komponen utama dalam pendidikan. Pendidik dalam pendidikan Islam dipanding sebagai kewajiban agama bagi seseorang yang bertanggung jawab atas pendidikan dirinya dan orang lain. ${ }^{4}$ Dewasa ini justru tidak sedikit ditemukan pendidik egois dalam melakukan tugasnya dan dan bersifat transaksional. Bukan lagi dilandaskan keihklasan dan rasa kemanusiaan untuk mengembangkan fitrah peserta didik. ${ }^{5}$

1 Tamuri Halim dan Muhammad Khairul Ajuhari. 2010. "Amalan Pengajaran Guru Pendidikan Islam Berkesan Berteraskan Konsep Mu'allim." Journal of Islamic and Arabic Education. Vol. 2. No. 1, hal: 4356.

2 Tamuri Halim., Jaafar Mustapha., dan Rhozin Ya. 2012. Konsep Berilmu di Kalangan Guru Pendidikan Islam Satu Keperluan dalam Membangunkan Modal Insan in Seminar Antarabangsa Perguruan dan Pendidikan Islam (SEAPPI2012) (International Seminar on Teacher and Islamic Education (SEAPPI2012]) at Le Grandeur Palm Resort, Senai, Johor Bahru on 8-9 March, hal: 289

3 Jajang Badruzaman. 2017. "Pemikiran Ahmad Tafsir Tentang Guru Dalam Pendidikan Islami dan Relevansinya Dengan Sistem Pendidikan Nasional." Tawazun: Jurnal Pendidikan Islam, 10 (2), hal: 316317.

4 Ilham Agam. 2017. "Pendidik dan Tenaga Kependidikan dalam Perspektif Hadist." Sabilarrasyad: Jurnal Pendidikan Dan Ilmu Kependidikan, 2 (2), hal: 126

5 Salminawati. 2016. “Etika Pendidik Perspektif Imam Al-Nawawi." Miqot: Jurnal Ilmu-Ilmu Keislaman. 40 (2), hal: 289. 
Banyak sekali praktik yang menggambarkan bahwasanya pendidik kurang profesional dalam menjalankan amanahnya.

Kemungkinan-kemungkinan masih adanya pendidik yang lebih mementingkan kegiatan keluarga, urusan pribadinya, meninggalkan kelas atau tidak mengajar dan mendidik, tidak mau menerima masukan siswanya, tidak mengembangkan profesinya, membawa urusan diluar ke dalam kelas, dan berperilaku yang tidak semsetinya dilihat anak kerap ditemui seperti merokok, duduk di meja, berkata tidak sopan masih dijumpai. Dapat dikatakan, jika hal ini dibiarkan berjalan tanpa pembenahan maka output yang dihasilkan tidak jauh berbeda dari yang menghasilkan mengingat pendidik adalah figur yang dicontoh pengalamannya secara teoritis maupun praktis. ${ }^{6}$

Pendidik harus mempunyai sifat-sfat yang baik disamping juga harus mempunyai skill kependidikan. Sifat-sifat pendidik yang baik diharapkan lebih mampu dalam memahami kebutuhan peserta didik dalam mengembangkan seluruh potensi yang dimilikinya. Sifat-sifat ini merupakan satu kesatuan dengan kewajiban pendidik dalam mendidik dan mengajar. ${ }^{7}$ Kaitannya dalam pendidikan Islam, pendidik memiliki tugas untuk mengarahkan peserta didik menjadi muslim yang bersih dan suci hatinya kembali ke fitrah manusia. Dan menyempurnakan peserta didik dengan pengetahuan dan nilai-nilai agama. ${ }^{8}$ Mau dibawa kemana peserta didiknya merupakan hasil dari kepribadian pendidik, dengan karakter dan keyakinan pendidik. Pendidikan akan memiliki arah yang jelas sepanjang pendidik menyadari perannya. Semakin tidak sadar pendidik pada perannya, maka arah pendidikan semakin tidak jelas. ${ }^{9}$

Kompetensi yang wajib dimiliki pendidik salah satunya adalah kompetensi kepribadian. Pembahasa sebelumnya merupakan gambaran mengenai urgensi kelayakan kompetensi kepribadian dalam pembelajaran. Kasus-kasus dalam lapangan masih membuktikan tidak sedikit pendidik yang melakukan kesalahan dalam pembelajaran.

Sebab itu, akan diperbincangkan bagaimana kepribadian guru yang profesional perspektif pendidikan Islam. Seorang pendidik harus mampu membuat peserta didiknya belajar untuk mengembangkan potensinya. Karena apupun strategi pembelajaran yang digunakan selalu

${ }^{6}$ Nur Hidayah. 2016. “Persepsi Mahasiswa Akuntansi Terhadap Etika Pendidik Pada Program Studi Akuntansi Universitas Muhammadiyah Ponorogo." Ekuilibrium: Jurnal Ilmiah Bidang Ilmu Ekonomi, 11(1); hal: 12.

${ }^{7}$ Sukring. 2016. “Pendidik Dalam Pengembangan Kecerdasan Peserta Didik.” Tadris: Jurnal Keguruan dan Ilmu Tarbiyah. 01(1), hal: 72

${ }^{8}$ Heru Juabdin Sada. 2015. "Pendidik dalam Perspektif Al-Qur'an. Al-Tadzkiyyah". Jurnal Pendidikan Islam. 6(1), hal; 98

${ }^{9}$ Aly Hery Noer. 2010. "Arti Penting World View Pendidik dalam Pendidikan." Ta'dib: Journal of Islamic Education. 15(1), hal: 109 
menampilkan keperibadian pendidik yang akan menjadi sorotan dan contoh peserta didik. ${ }^{10}$ Kompetensi kepribadian pendidik diharapkan ada pembenahan sehingga dapat melahirkan pendidik yang mampu menyampaikan materi, mampu mengontrol peserta didik dalam kelas, dapat memimpin proses pembelajaran, dan layak menjadi teladan yang baik bagi peserta didik dan masyarakat. ${ }^{11}$

\section{Metode Penelitian}

Penelitian ini menggunakan pendekatan kualitatif. Penelitian kualitatif merupakan peneleitian yang tidak menggunakan perhitungan statistika, namun melalui pengumpulan data dan menganalisisnya untuk kemudian diinterpretasikan dan dinarasikan. ${ }^{12}$ Data yang digunakan dalam penelitian ini merupakan hasil analisa antar sumber bacaan yang relevan dengan pembahasan yang akan dikaji dalam penelitian ini. Metode pengumpulan data yang dipakai adalah studi kepustakan, yaitu sebuah penelitian yang berusaha mengumpulkan sebanyak mungkin informasi relevan dengan masalah yang akan dikaji lebih dalam. ${ }^{13}$ Data pustaka yang digunakan dalam penelitian ini diperoleh peneliti dengan melakukan pencarian dan penggalian informasi terhadap buku, artikel jurnal, dan sumber lain yang relevan dengan masalah dalam penelitian.

\section{Peran Pendidik}

Sudah sering ditemukan pengertian pendidik dalam peraturan perundang-undangan dan pemikiran tokoh-tokoh barat. Dalam tulisan ini akan dibahas tentang pendidik dalam pendidikan Islam. Sebelumnya, pendidik selalu disangkut pautkan kepada orang yang mentransfer ilmu pengetahuan kepada orang lain. Namun, peran pendidik bukan sebatas transfer ilmu, di sini sama-sama akan kita ketahui perihal pendidik lebih luas, yang meliputi definisi, tugas, kedudukan, sifat yang harus dimiliki, serta kode etik pendidik. Ini diharapkan agar dapat menjadi masukan kepada khalatak luas.

Pendidik adalah orang dewasa yang berupaya mengembangkan potensi peserta didik secara keseluruhan yang meliputi ranah afektif, kognitif, dan psikomotrik. Berangkat dari pendidikan Islam, terdapat beberapa term bahasa Arab terkait pendidik yakni, mu'allim, mursyid, murabbi, m'uaddib, mudarris, dan ustadz. Istilah-istilah tersebut mengandung makna yang harus ada dalam diri seorang pendidik. ${ }^{14}$ Keenam istilah bagi guru diatas memiliki karakterisitik yang berbeda-beda.

10 Anwar Saepul. 2011. "Studi Realitas Tentang Kompetensi Kepribadian Guru Pendidikan Agama Islam Sekolah Menengah Atas Di Kabupaten Bandung Barat." Ta'lim: Jurnal Pendidikan Agama Islam. 9(2), hal; 147.

${ }^{11}$ Hadi Hadijah dan Nur Darojah. 2016. "Analisis Pengaruh Kompetensi Kepribadian Guru Dengan Motivasi Belajar Sebagai Variabel Intervening Terhadap Prestasi Belajar Siswa Kelas X Administrasi Perkantoran." JP Manper: Jurnal Pendidikan Manajemen Perkantoran. 1(1), 110.

${ }^{12}$ Anggito. 2009. 2018. Metodologi penelitian kualitatif. Sukabumi: V Jejak Publisher, hal: 9

${ }^{13}$ I Made Indra. 2019. Cara Mudah Memahami Metodologi Penelitian. Yogyakarta:Deepublish, hlm: 26

${ }^{14}$ Azima Dimyari. 2019. Pengembangan Profesi Guru. CV. GRE PUBLISHING. Yogyakarta, hal: 15-17 
Istilah mu'allim sering digunakan pada seseorang yang menguasai ilmu dan dapat menjelaskannya dari segi teoritis dan praktis dengan tujuan mentransferkannya sehingga diinternalisasi dan diamalkan orang lain. Mu'allim diartikan seorang guru yang alimun atau ilmuwan, yakni berusaha menguasai ilmu teoritik, mempunyai kreativitas, dan komitmen dalam mengembangkan ilmu serta mengamlkannya dengan tetap menjunjung tinggi nilainilai kehidupan sehari-hari. Guru sebagai mu'allim mempunyai tugas religius membagikan keilmuwannya kepada muslim lain dalam upaya mencerdaskan ummat seperti seperti Nabi Muhammad Saw. pada masanya. Guru sebagai ilmuwan memiliki kelayakan sebagai sumber pengetahuan peserta didiknya. ${ }^{15}$

Sementara itu mudarris ditujukan pada orang yang memiliki kapasitas intelektual dan informasi, serta mengembangkan profesinya secara berkelanjutan. Seorang guru di tingkat mudarris berusaha mencerdaskan dan melatih keterampilan peserta didik sesuai minat, bakat, dan kemampuan. ${ }^{16}$

Dalam dunia pendidikan Islam guru mempunyai beberapa peranan penting dalam mengembangkan potensi peserta didik. Seperti yang dijelaskan di muka, tugas utama guru adalah mengajar dan mendidik. Namun jika hanya begitu, sangat kecil peran guru dalam usaha mencerdaskan anak bangsa. Lebih dari itu, beberapa peneliti memberi beberapa peran guru yang sangat kompleks.

Guru memiliki lima peran utama, yakni sebagai pengajar dan pendidik, sebagai motivator, sebagai fasilitator, pembimbing, dan evaluator. Lebih lengkap, peneliti lain menyatakan peran guru terdiri dari mengajar dan membimbing, pelatih dan penasehat, pembaharu atau innovator, suri tauladan, motivator, tenaga profesional kependidikan, pembawa cerita atau analogi, emansipator, pengawet budaya, kulminator pendidikan, peneliti dan evaluator. ${ }^{17}$

Sejatinya begitu banyak peran yang dimainkan guru sehingga diharapkan guru yang tulus dalam menjalankan amanahnya mencerdaskan bangsa, bukan sekadar tuntutan pekerjaan apalagi perihal transaksional. Dengan banyaknya peran yang dimainkan oleh guru, harapannya mampu menginternalisasikan nilai-nilai kepada siswa sehingga tiga kompetensi pendidikan yakni kognitif, afektif, dan psikomotorik terasah.

\section{Kompetensi Kepribadian Pendidik}

Kepribadian dalam pandangan psikologi umum dan psikologi Islam tidak jauh terlepas id sebagai nafsu (fitrah hayawaniyah), ego sebagai akal (fitrah insaniah), dan superego sebagai hati (fitrah ilahiyah) yang saling melengkapi. ${ }^{18}$ Penulis mengindikasikan tiga komponen

15 Ahmad Syamsu Rizal. 2014. "Filsafat Pendidikan Islam Sebagai Landasan Membangun Sistem Pendidikan Islami." Ta’lim: Jurnal Pendidikan Agama Islam 12 (1), hal: 13

${ }^{16}$ Indah Failatul Kasmar, dkk. 2019. "The Concepts of Mudarris, Mu'allim, Murabbi, Muaddib in Islamic Education." Khalifa: Journal of Islamic Education. 3 (2), hal: 111.

${ }^{17}$ Juhji, J. 2016. “Peran Urgen Guru dalam Pendidikan.” Studia Didaktika, 10 (01), 55-59.

${ }^{18}$ Muhimmatul Hasanah. 2018. “Dinamika Kepribadian Menurut Psikologi Islami.” UMMUL QURA, 11(1), hal: 121. 
inilah yang membentuk kepribadian. Penulis pernah membaca sekitar dua tahun yang lalu, keterkaitan antara tiga komponen kepribadian dapat dianalogikan dengan kasus makan. Makan adalah kebutuhan manusia yang didorong oleh id atau nafsu, kemudian rasa lapar oleh nafsu mendorong seseorang untuk makan. Ketika orang tersebut tidak mempunyai makanan dan tidak memiliki uang untuk membeli makan, orang tersebut bergerak ke warung tetangganya untuk mencuri makanan. Namun superego sebagai polisi kepribadian yang berangkat dari hati nurani dan berlandaskan kebaikan mengatakan jangan dilakukan.

Kompetensi kepribadian harus dimiliki oleh guru dengan berlandaskan kepada UndangUndang Nomor 14 Tahun 2005 Tentang Guru dan Dosen. Pada pasal 8 disebutkan bahwa guru harus memiliki empat kompetensi, yakni kompetensi pedagogik, kompetensi kepribadian, kompetensi sosial, dan kompetensi profesional. Kemudian tentang kompetensi kepribadian dijelaskan dalam Peraturan Pemerintah RI Nomor 19 Tahun 2005 Pasal 28 ayat 3 Tentang Standar Nasional Pendidikan, kompetensi kepribadian adalah adalah kemampuan kepribadian yang mantap, stabil, dewasa, arif, dan berwibawa, menjadi teladan bagi peserta didik, dan berakhlak mulia.

Dalam kompetensi kepribadian, guru dalam menjalankan profesinya harus memperhatikan hal-hal sebagai berikut. Pertama, guru harus memperhatikan nilai-nilai etika. Kedua, guru harus menjaga perilakunya. Ketiga, guru diminta untuk memiliki kepribadian yang unggul. Ini didukung dengan pernyataan bahwa guru dalam pendidikan Islam dituntu untuk memiliki sifat-sifat kepribadian yang unggul, memiliki karakter, serta penokohan sehingga dalam pembelajaran mampu memberi kesan. ${ }^{19}$

Untuk lebih mendalami tiga pernyataan di atas, terdapat empat hal yang dapat digunakan sebagai acuan untuk memahami kompetensi kepribadian guru, yaitu memperhatikan nilainilai etika, menjaga perilaku, dan menjadi pribadi unggul. Guru adalah teladan bagi peserta didik dan masyarakat, maka menjaga perilaku wajib bagi seorang guru. Berperilaku yang dapat mencerminkan pribadi yang berakhlak mulia kepada sesama dan takwa kepada Tuhan Yang Maha Esa. Guru diharapkan memiliki pribadi yang stabil, mantap, dan matang dalam setiap gerak-geriknya. Dewasa, bijaksana, dan arif dalam memutuskan sesuatu sehingga berwibawa bagi anak didiknya. Rofa'ah menambahkan kelengkapan dengan pernyataan bahwa seorang guru harus menjunjung tinggi kode etik. Kode etik guru meliputi, menunjukkan etos kerja, tanggung jawab, dan bangga terhadap profesinya. ${ }^{20}$

\section{Kode Etik Guru}

Kode etik merupakan pedoman bersikap dan berperilaku guru sesuai norma dan etika sebagai seroang guru. Adanya kode etik adalahh untk mewujudkan guru yang profesional dalam mengemban amanah profesi. Kode etik ditetapkan oleh organisasi pemerintah yang

\footnotetext{
${ }^{19}$ A.H. Tamuri., Ismail, M. F., \& Jasmi, K. A. 2012. Komponen Asas untuk Latihan Guru Pendidikan Islam: Basic Components for Islamic Education Teacher Training. Global Journal Al-Thaqafah, 2(2), hal: 59 .

20 Rofa'ah. 2016. Pentingnya Kompetensi guru Dalam Kegiatan Pembelajaran Dalam Perspektif Islam. Deepublish. Yogyakarta, hal: 73
} 
berwenang pada suatu kongres organisasi profesi. Pedoman ini harus ditaati oleh guru, sebab jika dilanggar akan mendapatkan sanksi bagi siapa saja yang melakukannya.

Undang-Undang Nomor 14 Tahun 2005 Pasal 43 Ayat 1 Tentang Guru Dan Dosen menyatakan bahwa untuk menjaga dan meningkatkan kehormatan dan martabat guru dalam pelaksanaan tugas profesinya, organisasi profesi guru membentuk kode etik. Pada pasal 2, disebutkan bahwa adanya kode etik berisikan norma dan etika yang mengikat perilaku guru dalam pelaksanaan tugas profesinya.

Kode etik guru disusun sebagai berikut: a) Guru berbakti dalam membimbing anak didik untuk membentuk manusia berjiwa Pancasila; b) Guru memiliki kejujuran dan professional; c) Guru berupaya memperoleh informasi tentang peserta didik sebagai bahan pertimabangan dalam membimbing dan membinanya; d) Guru menciptakan suasana kehidupan sekolah dan memelihara hubungan dengan masyarakat dengan sebaik-baiknya untuk menunjang proses pembelajaran; e) Guru memelihara hubungan baik orang tua murid dan masyarakat untuk yang lebih luas untuk kepentingan pendidikan yang merupakan tanggung jawab bersama; f) Guru berusaha mengembangkan dan meningkatkan kemampuan profesinya secara pribadi maupun kelompok; g) Guru menciptakan dan memelihara hubungan antara sesama guru baik berdasarkan lingkungan kerja maupun di dalam hubungan keseluruhan; h) Guru secara bersama-sama memelihara, membina dan meningkatkan mutu organisasi guru profesional sebagai sarana pengabdiannya; i) Guru melaksanakan segala ketentuan yang merupakan kebijakan pemerintah dalam bidang pendidikan.

\section{Kompetensi Kepribadian Guru Perspektif Islam}

Kepribadian guru dalam sudut pandang Islam diambil dari pembahasan sebelumnya terkait pengertian dan kedudukan guru dalam Islam dan kompetensi kepribadian guru yang masih universal. Nilai-nilai yang diturunkan dari pembahasan sebelumnya diharapkan mampu mengkontruksi kompetensi kepribadian guru perspektif Islam.

Sebab itu, dapat ditarik beberapa poin kepribadian yang harus dimiliki oleh seorang guru, di antaranya sebagai berikut: Pertama, Berjiwa Pemimpin. Guru merupakan orang tua peserta didik ketika berada di lingkungan sekolah. Jika perempuan maka sebagai ibu dan jika guru laki-laki maka bertindak selayaknya ayah. Untuk mendidik, membimbing, dan membina peserta didik maka diperlukan jiwa pemimpin. Rasulullah Saw. bersabda, "setiap kamu adalah pemimpin, dan setiap pemimpin akan dimintai pertanggung jawaban atas apa yang dibawah kepemimpinannya". (HR. Bukhari). Penjelasannya, seorang guru memiliki tanggung jawab untuk mengantar orang yang dipimpinnnya, dalam hal ini adalah mengantar peserta didik yang dibina, dibimbing, dan didik untuk mencapai tujuan dan akan dimintai pertanggung jawaban. ${ }^{21}$ Kedua, Menjadi Suri Tauladan. Guru sebagai suri tauladan bermakna guru merupakan panutan atau contoh dalam berucap maupun bertindak. ${ }^{22}$ Guru merupakan rule model bagi peserta didik. Maka, seorang guru

\footnotetext{
${ }^{21}$ M. H. Ginanjar. 2017. “Keseimbangan Peran Orang Tua dalam Pembentukan Karakter Anak.” Edukasi Islami: Jurnal Pendidikan Islam, 2(03). 236.

${ }^{22}$ C. Muali \& K. R. Qodratillah. 2018. "Pengembangan Karakter Guru dalam Menghadapi Demoralisasi Siswa Perspektif Teori Dramaturgi." Jurnal MUDARRISUNA: Media Kajian Pendidikan Agama Islam, 8 (1), 103.
} 
harus konsisten juga dengan karakter atau penokohannya sebagai tenaga pendidik profesional dalam bertingkah laku. Suri tauladan ini sebenarnya mewakili poin-poin keperibadian lainnya. Di mana nantinya yang akan dicontoh oleh peserta didik bukanlah istilah suri tauladan, melainkan kepribadian yang dapat dicontoh dari seorang guru. Kepribadian yang patut dicontoh itulah yang menjadikan guru menjadi suri tauladan bagi anak didiknya.

1) Beriman dan Berilmu. Dalam surah Al-Mujadalah ayat 11, dijelaskan bahwa Allah Swt. akan mengangkat derajat orang yang beriman dan berillmu.

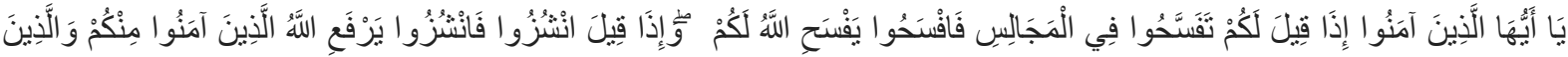

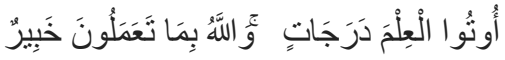

Artinya, "wahai orang yang beriman, apabila dikatakan kepadamu, berilah kelapangan di majelis-majelis, maka lapangkan. Niscaya Allah Swt. akan memberi kelapangan untukmu. Apabila dikatakan berdirilah kamu, maka berdirilah. Niscaya Allah Swt. akan mengangkat (derajat) orang-orang yang beriman diantaramu dan orang-orang yang diberi ilmu beberapa derajat. Allah Swt. Maha Teliti apa yang kamu kerjakan".

Guru merupakan profesi yang mulia. Maka sebagai guru muslim, seorang guru harus meniatkan profesinya untuk mencerdaskan kehidupan ummat manusia. Guru diminta untuk berpengetahuan atau berilmu sebab profesinya adalah mentransisikan pengetahuan atau ilmu darinya kepada peserta didik. Dengan ilmu juga, guru menjadi profesional. Ahli dalam bidang keilmuan yang diajarkannya dan mampu melaksanakan tugas keguruan dengan baik.

2) Ikhlas. Guru perspektif pendidikan Islam dianggap harus memiliki kepribadian ikhlas. Ikhlas memiliki arti membersihkan niat dari debu duniawi dan memantapkan tujuan untuk mencari ridha Allah Swt. Ikhlas dalam pelaksanaanya bagi guru adalah maksimal dalam berkerja, tidak kenal lelah, dan terus berupaya untuk mengembangkan potensi peserta didik secara keseluruhan.

Tentang ikhlas, dalam surah Al-An'am ayat 162 yang artinya "Sesungguhnya shalatku, ibadahaku, hidupku, dan matiku hanya untuk Allah, tuhan seluruh alam".

Ayat tersebut dapat dijadikan titik awal segala niat tersandarkan, dalam artian untuk mengingat bahwa segala yang dikerjakan manusia semata untuk Allah Swt. tuhan semesta alam. Jika amal atau suatu pekerjaan diniarkan ikhlas lillahi ta'ala, maka yang berat bisa ringan, yang sukar bisa muda, yang lama tak terasa menjadi sebentar, dan yang jauh didekatkan.

3) Dakwah Islam. Dakwah Islam yang dimaksud di sini adalah memberi pemahaman Islam yang lurus sesuai Al-Qur'an dan Hadist, serta sumber rujukan umat Islam yang lain. Amar ma'ruf nahi munkar juga perlu ditanamkan. Bagi guru yang berada di bidang disiplin ilmu umum, bisa mengintegrasikan nilai-nilai Islam dalam materi pembelajaran dan pembawaan guru ketika berada di hadapan siswanya.

Dakwah Islam dan amar ma'ruf nahi munkar ini berkenaan dengan ucapan Rasulullah Saw, "sampaikan oleh mu daripadaku walau satu ayat sekali pun". (HR. Tirmidzi, Bab Ma Ja a fil alHadith an' Bani Israel, No. Hadist 2593). Dalam hadist ini diberitakan bahwa dakwah Islam bukan 
saja dilakukan oleh suatu profesi tertentu misalnya para ulama. Namun juga dilakukan oleh guru atau umat Islam secara keseluruhan. ${ }^{23}$

4) Optimis atau Pantang Menyerah. Merujuk kepada pengertiannya, optimis bisa diartikan sebagai tidak mudah menyerah. Seorang guru dalam melaksanakan tugas profesinya harus tetap semangat, kreatif, dan inovatif dalam mengembangkan potensi peserta didik secara keseluruhan. Ketika dihadapkan dengan karakter dan kemampuan peserta didik yang berbeda-beda dan sulit diperkirakan maka seorang guru harus bisa menyelesaikan tantangannya.

Sikap optimis ini tergantung kepada niat guru di awal. Jika memang diniatkan karena Allah Swt. maka seorang guru akan optimis dan pantang menyerah dalam mencerdaskan anak didiknya. Abdul Hamid menyebutkan penyandaran diri kepada Allah Swt. atas kekuasaan dan kekuatanNya akan menimbulkan sikap optimis pada diri seseorang yang ditandai dengan berpikir positif, bahagia, bersyukur, dan rasa senang atau cinta pekerjaan. ${ }^{24}$

5) Berakhlak Mulia. Berakhlak mulia berarti melakukan tindakan-tindakan terpuji menurut sudut pandang Islam. Sedangkan tindakan-tindakan tidak terpuji maka disebut akhlak yang buruk. Maka, untuk membedakan akhlak mulia dan akhlak yang buruk, seorang guru perlu mendalami konsep akhlak itu sendiri. ${ }^{25}$ Guru memiliki tanggung jawab moral sebagai contoh anak didiknya, maka teladan yang baik harus ditunjukkan oleh guru kepada anak didiknya.

Visi besar seorang guru dapat merujuk pada hadist nabi berikut, Nabi Muhammad Saw. bersabda yang artinya: "sesungguhnya aku diutus Allah untuk menyempurnakan akhlak (budi pekerti)". (HR. Bukhori).

Peran guru layaknya Nabi Muhammad Saw. pada masanya. Memperbaiki keadaan umat dengan pengetahuan-pengetahuan baru agar memiliki peradaban yang baik dan lebih baik lagi. Bedanya, Nabi Muhammad mendapat perintah langsung dari Allah Swt., sedangkan para guru melanjutkan dakwah Nabi.

6) Penyayang. Indikator penyayang menurut Anastasia (2017:38) adalah seorang yang ramah dan perhatian. Guru dalam melaksanakan tugas profesi, khususnya dalam berinteraksi dengan peserta didik hendaklah ramah dan perhatian. Dengan perlakuan seperti itu, maka misi untuk mengembangkan potensi peserta didik yang diniatkan karena Allah Swt. untuk berdakwah akan terjiwai oleh peserta didik. Sebaliknya jika seorang guru berlaku arogan dan menunjukkan raut muka yang tidak mengenakkan, maka peserta didik sukar menerima materi pelajaran dan hikmah di dalamnya.

Ini dsebutkan dalam surah Ali 'Imran ayat 159 yang artinya, "maka disebabkan rahmat dari Allahlah kamu berlaku lemah lembut terhadap mereka. Sekiranya kamu keras lagi berhati kasar,

\footnotetext{
23 A.M. Baharudin. \& H. M. T Jamil. 2016. Ilmu Makki Dan Madani dan Kepentingannya bagi Pendakwah. Al-Irsyad: Journal of Islamic and Contemporary Issues, 1(1). 49.

24 Abdul Hamid. 2017. Hamid, Abdul. (2017). “Agama dan Kesehatan Mental Dalam Perspektif Psikologi Agama." Healthy Tadulako Journal: Jurnal Kesehatan Tadulako, 3 (1), hal: 1

${ }^{25}$ Selly Sylviyanah. 2012. "Pembinaan Akhlak Mulia Pada Sekolah Dasar." Jurnal Tarbawi Vol, 1(3), hal: 193.
} 
tentulah mereka menjauhkan diri dari sekelilingmu. Karena itu maafkanlah mereka, mohonkanlah ampun bagi mereka, dan bermusyawarahlah dengan mereka dalam urusan itu."

Jika dihubungkan kepada profesi guru, sifat penyayang harus dimiliki oleh seorang guru idaman. Jika tidak, kemungkinan besar peserta didik akan menjauh atau tidak menyukai kepribadian guru. Sedangkan sifat sayang nabi kepada umatnya dituliskan pada Q.S At-Taubah ayat 128

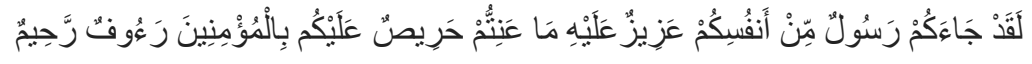

Artinya: "sesungguhnya telah datang kepadamu seorang rasul dari kaummu sendiri, yang berat memikirkan penderitaanmu, sangat mengingkan kamu(beriman dan selamat), amat belas kasihan lagi penyayang terhadap orang-orang mu'min".

Untuk itu, kepribadian Nabi Muhammad Saw., sebagai teladan utama umat muslim harus dipelajari, khususnya bagaimana beliau berlaku sangat penyayang terhadap umatnya.

7) Bertanggung Jawab. Tanggung jawab seorang guru adalah menjalankan tugas profesinya hingga selesai. Contoh sederhananya, seorang guru yang sudah membuka proses pembelajaran maka harus melakukan serangkaian proses pembelajaran hingga penutup. Dalam surah Al-Muddatsir ayat 38 yang artinya, "Tiap-tiap diri bertanggung jawab atas apa yang telah diperbuatnya".

Tanggung jawab seorang manusia dalam tulisan ini terbagi menjadi tiga, yakni kepada Allah Swt, kepada sesama atau dalam hal ini peserta didik, dan kepada lingkungan sekitar atau dalam hal ini amanah profesi.

8) Senang Berbagi. Peran guru dilihat dari caranya berinteraksi dengan peserta didik, sesama guru, dan masyarakat. Guru sebagai pendidik maka harus mau berbagi ilmu yang dimilikinya sampai peserta didik benar-benar paham. Selain itu pengalaman hidup perlu diberikan kepada peserta didik dengan tujuan sebagai motivasi. Kepada sesama guru dan masyarakat berbagi bisa dalam bentuk moril maupun materi. Jika rezeki itu bermacam bentuknya, maka seruan Allah Swt. untuk berbagi rezeki kepada orang lain bisa dengan berbagi ilmu dan pengalaman hidup, tenaga, waktu, pikiran, harta atau hadiah kepada peserta didik untuk menuju ke peradaban Islam yang lebih baik.

9) Taat Kepada Hukum. Guru harus taat kepada hukum negara, hukum syariat, dan hukum masyarakat. Hukum negara bagi guru ditaati untuk menjadi tenaga pendidik profesional dalam bidangnya. Yakni memiliki kualifikasi, kompetensi, dan kompetensi seperti yang diterangkan dalam Undang-Undang Nomor 14 Tahun 2005 Tentang Guru dan Dosen, sedangkan dalam pelaksanaan tugasnya harus memenuhi kode etik guru.

Hukum syariat digunakan oleh guru untuk menjadi pribadi yang baik sesuai tuntunan ajaran agama Islam. Guru menaati perintah Allah Swt. berupa menjalankan perintahnya dan menjauhi larangannya. Sedangkan dalam menaati hukum masyarakat atau norma etika merupakan upaya guru untuk menghargai norma etika yang berlaku di tempatnya diperkerjakan. Selain itu juga agar mudah berbaur dengan wali murid dan muridnya.

10) Menjunjung Tinggi Kejujuran. Sikap jujur sangat diperlukan jika melihat fenomena degradasi moral di penjuru dunia termasuk pada bangsa kita. Kejujuran adalah pangkal dari semua kebaikan dan kebohongan atau tidak jujur adalah awal dari sebuah kejahatan. Inilah mengapa dalam QS. Al-Maidah ayat 119, yang artinya: 
"Inilah saat orang yang jujur memperoleh manfaat dari kejujurannya. Mereka memperoleh surge yang dibawahnya mengalir sungai-sungai, mereka kekal di dalamnya selamalamanya. Allah ridha kepada mereka dan mereka pun ridha kepada-Nya. Itulah kemenangan yang agung".

Sesungguhnya Allah Swt. maha mengatuhi apa yang dikerjakan oleh seluruh makhluk yang diciptakan-Nya. Dalam QS. At-Taubah ayat 115, Allah berfirman:

$$
\text { إِنَّ اللَّهَ عَلِيمٌ بِذَاتِ الصنُدُورِ }
$$

Artinya, "sesungguhnya Allah mengetahui apa yang ada di dalam dada".

Sedangkan untuk yang menebar kebohongan maka azab Allah sangat pedih, seperti dalam kalamullah pada QS. Al-Baqarah ayat 8-10 yang menjelaskan ketika seseorang itu melakukan kebohongan maka sejatinya orang tersebut sedang membohongi diri sendiri tanpa bisa mereka sadari. Kebohongan adalah sebuah penyakit hati manusia, seorang pembohong akan disesatkan oleh Allah Swt dan mendapatkan azab yang pedih dari perbuatannya.

11) Beriman dan Bertakwa. Dalam QS. Al-Hujarat ayat 13, Allah berfirman:

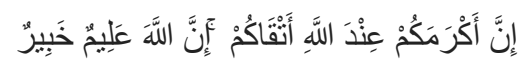

Artinya, "Sesungguhnya orang yang paling mulia di antara kamu di sisi Allah ialah orang yang paling bertakwa".

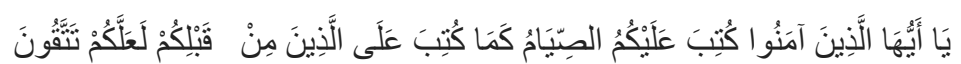
Artinya, "hai orang-orang yang beriman, diwajibkan atas kamu berpuasa sebagaimana diwajibkan atas orang-orang sebelum kamu agar kamu bertakwa". (QS. Al-Baqarah: 183)

Pengertian bertakwa harus disandingkan dengan istilah beriman. Seorang yang bertakwa akan merasa dirinya adalah hamba Allah Swt. dan berusaha untuk beriman kepada-Nya yang dibuktikan dengan mentaati perintah-Nya. Takwa adalah praktik kehidupan yang sesuai dengan panduan ajaran agama Islam secara kaffah atau sempurna. ${ }^{26}$

12) Bijaksana. Guru dalam berkata, bersikap, dan bertindak harus bijaksana. Menggunakan pemikiran matang dalam membuat sebuah keputusan. Di mana keputusan dibuat dengan mempertimbangkan akal budi atau pengalaman dan pengetahuan. Tindakan guru juga perlu mempertimbangkan ketiga hukum yang disebutkan di bagian taat. Dapat dikatakan guru yang bijaksana akan mengolah kecerdasan intelektual, kecerdasan emosional, dan kecerdasan spiritual sebelum berkata, bersikap, dan bertindak. Dengan begitu seorang guru akan lebih tajam dalam memperkirakan dampak dari keputusannya.

13) Sabar. Peserta didik memiliki karakter dan kemampuan yang berbeda. Ini harus diketahui oleh seorang guru agar tidak memaksakan anak didiknya harus seperti ini atau

${ }^{26}$ Atmonadi. 2018. Menaklukkan Gunung Kesombongan Jiwa. Atmoon Self Publishing, hal: 13. 
seperti itu. Kesabaran diperlukan dalam mendidik, membimbing, melatih, dan membina anak didik. Kesabaran akan berbuah hasil kebaikan. Agar menghasilakn buah maka dibutuhkan upaya oleh seorang guru dalam memahami perbedaan peserta didik. Allah Swt. berfirman dalam QS. Al-Baqarah ayat 45 yang artinya:

"Jadikanlah sabar dan shalat sebagai penolongmu. Dan sesungguhnya yang demikian itu amat berat, kecuali bagi orang-orang yang khusyu".

14) Menjaga Silahutrahmi. Silahturahmi mendatangkan kedamaian yang dilandasi rasa persaudaraan dan kekeluargaan. Kedamaian dari silahturahmi bisa dicontoh dari hadist Nabi Muhammad Saw., beliau bersabda yang artinya: "Wahai manusia, tebarkanlah salam, berikanlah makan, sambung silaturahim, shalatlah pada malam hari ketika orang-orang sedang tidur, kalian akan masuk surge dengan selamat." (HR. Ibnu Majah dan At-Tirmidzi).

Silahturahmi yang dilakukan guru dalam profesinya adalah dengan sesama guru, wali siswa, masyarakat, dan siswanya. Ini bisa dilakukan dengan 1) saling menebar salam, 2) menjaga hubungan baik, 3) saling membantu, 4) menjalin komunikasi dengan wali siswa dan masyarakat, 5) mendengarkan aspirasi siswa, wali siswa, dan masyarakat, ataupun rekan kerja, 6) rajin dan ikhlas berbagi ilmu pengetahuan, pengalaman hidup, maupun sebagian harta.

15) Berkemauan Terus Belajar. Setiap muslim harus mencari ilmu pengetahuan. Ini disampaikan oleh Rasulullah Saw., beliau bersabda yang artinya, "menuntut ilmu itu wajib atas setiap muslim". (HR. Ibnu Majah). Sedangkan dalam al-Qur'an, Allah Swt berfirman dalam surah Thaaha ayat 114 yang artinya, "Dan katakanlah, wahai Rabn-ku, tambahkanlah kepadaku ilmu."

Seorang guru harus selalu belajar dalam artian untuk mengembangkan kemampuan, kepakaran, atau keahlian dalam menekuni profesinya. Oleh karena itu pembinaan dan pelatihan untuk mengembangkan profesi guru yang telah diprogramkan oleh pemerintah harus lebih digalakkan dan bisa diikuti oleh setiap guru. Selain itu, seorang guru juga harus mau dan sadar secara mandiri untuk tetap belajar dari media belajar yang tersedia bagi profesinya.

\section{Penutup}

Guru memiliki peran yang mulia. Kepribadian guru dinilai sangat penting sehingga pemerintah dalam peraturan perundang-undangan memaktubkan kompetensi kepribadian bagi profesi guru. Kompetensi kepribadian guru akan menentukan bagaimana seorang berperan dalam proses pendidikan. Sebagai mu'allim, mu'addib, mudarris, mursyid, murabbi, dan ustadz harus memperhatikan benar karakter dan kemampuan peserta didik yang berbeda. Guru mempunyai panduan kode etik yang diatur oleh negara. Kompetensi kepribadian yang munculkan dari sudut pandang Islam berjumlah tujuh belas poin. Kompetensi kepribadian guru perspektif Islam diharapkan mampu menggambarkan kepribadian muslim yang mulia dalam menjalankan profesi guru. Selain itu juga menjadi motivasi, rujukan, dan panduan bagaimana guru muslim bertindak profesional dalam menjalankan amanah profesi. 


\section{Daftar Pustaka}

Aly, Hery Noer. (2010). Arti Penting World View Pendidik Dalam Pendidikan. Ta'dib: Journal Of Islamic Education. 15(1), 105-120.

Andriani, Ayu. (2018). Praktis Membuat Buku Ajar Guru. CV Jejak Publisher. Sukabumi

Anggito. (2018). Metodologi penelitian kualitatif. Sukabumi:CV Jejak Publisher. Hlm. 9

Anggraeni, Anastasia. (2017). KOMPETENSI KEPRIBADIAN GURU MEMBENTUK KEMANDIRIAN ANAK USIA DINI (STUDI KASUS DI TK MUTIARA, TAPOS DEPOK). AWLADY: Jurnal Pendidikan Anak, 3(2), 28-47.

Anwar, Saepul. (2011). Studi Realitas Tentang Kompetensi Kepribadian Guru Pendidikan Agama Islam Sekolah Menengah Atas Di Kabupaten Bandung Barat. Ta'lim: Jurnal Pendidikan Agama Islam. 9(2), 145-159

Atmonadi. (2018). Menaklukkan Gunung Kesombongan Jiwa. Atmoon Self Publishing.

Aziz, Amrullah. (2015). Pendidik Profesional Yang Berjiwa Islami. Pancawahana: Jurnal Studi Islam, 10(1), 56-58.

Badruzaman, Jajang. (2017). Pemikiran Ahmad Tafsir Tentang Guru Dalam Pendidikan Islami Dan Relevansinya Dengan Sistem Pendidikan Nasional. Tawazun: Jurnal Pendidikan Islam, 10(2), 331-358.

Baharudin, A. M., \& Jamil, H. M. T. (2016). Ilmu Makki Dan Madani dan Kepentingannya bagi Pendakwah. Al-Irsyad: Journal of Islamic and Contemporary Issues, 1(1). 43-53.

Darimi, I. (2015). Peningkatan Kompetensi Pedagogik Guru PAI dalam Pembelajaran. Jurnal MUDARRISUNA: Media Kajian Pendidikan Agama Islam, 5(2), 309-324.

Dimyati, Azima. (2019). Pengembangan Profesi Guru. CV. GRE PUBLISHING. Yogyakarta

Ginanjar, M. H. (2017). Keseimbangan peran orang tua dalam pembentukan karakter anak. Edukasi Islami: Jurnal Pendidikan Islam, 2(03). 230-241

Hadijah, Hadi dan Darojah, Nur. 2016. Analisis Pengaruh Kompetensi Kepribadian Guru Dengan Motivasi Belajar Sebagai Variabel Intervening Terhadap Prestasi Belajar Siswa Kelas X Administrasi Perkantoran. JP Manper: Jurnal Pendidikan Manajemen Perkantoran. 1(1), 109118.

Hamid, Abdul. (2017). Agama dan Kesehatan Mental Dalam Perspektif Psikologi Agama. Healthy Tadulako Journal (Jurnal Kesehatan Tadulako), 3(1), 1-14.

Hasanah, M. (2018). Dinamika Kepribadian Menurut Psikologi Islami. UMMUL QURA, 11(1), 110122.

Hidayah, Nur. (2016). Persepsi Mahasiswa Akuntansi Terhadap Etika Pendidik Pada Program Studi Akuntansi Universitas Muhammadiyah Ponorogo. Ekuilibrium: Jurnal Ilmiah Bidang Ilmu Ekonomi, 11(1), 10-17.

Indra, I Made. (2019). Cara Mudah Memahami Metodologi Penelitian. Yogyakarta:Deepublish. Hlm. 26 
Juhji, J. (2016). Peran Urgen Guru dalam Pendidikan. Studia Didaktika, 10(01), 51-62.

Karyanto, Umum. (2011). Makna Dasar Pendidikan Islam (Kajian Semantik). Edukasia Islamika, 9 (2) $155-168$.

Kasmar, Indah Failatul, dkk. (2019). The Concepts Of Mudarris, Mu'allim, Murabbi, Muaddib in Islamic Education. Khalifa: Journal Of Islamic Education. 3(2), 107-125

Maisyaroh. (2019). Hakikat Pendidik Dalam Perspektif Falsasah Pendidikan Islami. Jurnal pendidikan Agama Islam Al-Thariqah. 4(2), 1-9

Muali, C., \& Qodratillah, K. R. (2018). Pengembangan karakter guru dalam menghadapi demoralisasi siswa perspektif teori dramaturgi. Jurnal MUDARRISUNA: Media Kajian Pendidikan Agama Islam, 8(1), 102-126.

Nizar, Samsul., dan Hasibuan, Zainal Efendi. (2018). Pendidik Ideal Bangunan Character Building. PRANAMEDIA GROUP. Depok.

Noor, F. A. (2017). Pendidikan Karakter Guru Raudlatul Athfal (RA) Berbasis Kehidupan Lebah. Golden Age: Jurnal Ilmiah Tumbuh Kembang Anak Usia Dini, 2(1), 16-28.

Rizal, Ahmad Syamsu. (2014). Filsafat Pendidikan Islam Sebagai Landasan Membangun Sistem Pendidikan Islami. Ta'lim: Jurnal Pendidikan Agama Islam 12(1), 1-18

Rofa'ah. (2016). Pentingnya Kompetensi guru Dalam Kegiatan Pembelajaran Dalam Perspektif Islam. Deepublish. Yogyakarta

Sada, Heru Juabdin. (2015). Pendidik Dalam Perspektif Al-Qur'an. Al-Tadzkiyyah: Jurnal Pendidikan Islam. 6(1), 93-105.

Sahan. (2011). The Conception Of Al-Qur'an on Exucator: Study Of QS. Ali Imran: 79. Madania: Jurnal Ilmu-Ilmu Keislaman. 1(1), 92-115

Salminawati. (2016). Etika Pendidik Perspektif Imam Al-Nawawi. Miqot: Jurnal Ilmu-Ilmu Keislaman. 40(2), 288-307.

Sarjana, S., \& Khayati, N. (2016). Pengaruh etika, perilaku, dan kepribadian terhadap integritas guru. Jurnal Pendidikan dan Kebudayaan, 1(3), 379-393.

Setiawan, Ilham Agam. (2017). Pendidik Dan Tenaga Kependidikan Dalam Perspektif Hadist. Sabilarrasyad: Jurnal Pendidikan Dan Ilmu Kependidikan, 2(2), 162-169.

Sukring. (2016). Pendidik Dalam Pengembangan Kecerdasan Peserta Didik. Tadris: Jurnal Keguruan dan Ilmu Tarbiyah. 01(1), 69-80.

Sylviyanah, Selly. (2012). Pembinaan Akhlak Mulia Pada Sekolah Dasar. Jurnal Tarbawi Vol, 1(3), 191.

Syukur, Fatah. 2017. Paradigma Baru Filsafat Pendidikan Islam. KENCANA. Depok

Tamuri, A. H., Ismail, M. F., \& Jasmi, K. A. (2012). Komponen Asas untuk Latihan Guru Pendidikan Islam [Basic Components for Islamic Education Teacher Training]. Global Journal AlThaqafah, 2(2), 53-63. 
Tamuri, Halim dan Ajuhari, Muhammad Khairul. (2010). Amalan Pengajaran Guru Pendidikan Islam Berkesan Berteraskan Konsep Mu'allim. Journal of Islamic and Arabic Education. 2(1), 43-56.

Tamuri, Halim., Mustapha, Jaafar., dan Ya, Rhozin. (2012). Konsep Berilmu di Kalangan Guru Pendidikan Islam Satu Keperluan dalam Membangunkan Modal Insan in Seminar Antarabangsa Perguruan dan Pendidikan Islam [SEAPPI2012] (International Seminar on Teacher and Islamic Education [SEAPPI2012]) at Le Grandeur Palm Resort, Senai, Johor Bahru on 8-9 March 289-303 